Darjan Karabasevic ${ }^{1}$, Dragisa Stanujkic ${ }^{2}$, Snezana Urosevic ${ }^{3}$, Gabrijela Popović ${ }^{4}$, Mladjan Maksimovic ${ }^{5}$ 1,5 5 niversity Business Academy in Novi Sad, Faculty of Applied Management, Economics and Finance, Jevrejska 24, Belgrade, Serbia 2, 4 John Naisbitt University, Faculty of Management in Zaječar, Serbia ${ }^{3}$ University of Belgrade, Technical Faculty in Bor, Serbia

\title{
An Approach to Criteria Weights Determination by Integrating the DELPHI and the Adapted SWARA Methods
}

DOI: 10.7595/management.fon.2017.0024

\begin{abstract}
The process of evaluation and selection of personnel is characterized by defining a specific set of criteria. The process of defining and determining the weights of the criteria is a significant, because the evaluation and the final selection of personnel are carried out on the basis of the defined set of criteria. Therefore, this manuscript is aimed at creating a set of the sales managers' evaluation criteria as well as defining the weights of such criteria. The survey sample was 79 domain experts in the field of the recruitment and selection of personnel. The proposed approach based on the integration of the Delphi technique and the adapted SWARA methods was successfully applied for the purpose of defining the weights of the criteria and completely responded to the requirements in terms of defining the criteria and determining the weights of the criteria.
\end{abstract}

Keywords: Evaluation criteria, sales manager, weights determination, SWARA, Delphi technique, MCDM. JEL Classification: D81, O15, C02

\section{Introduction}

A rapid development of the field of multiple-criteria decision making (MCDM), as an important part of operational research, has caused the creation of many methods for decision making. Bana e Costa and Pirlot (1997) point out that a significant development in the area of multiple-criteria decision-making started in 1972, when the international scientific community interested in the multi-criteria domain emerged in an organized form. As a significant subfield of operational research, MCDM deals with the evaluating and choosing/selecting of the best alternative based on several criteria (Hajiagha et al., 2016). Also, MCDM may be considered as a complex and dynamic process, inclusive of one managerial level and one engineering level (Duckstein \& Opricovic, 1980), where the managerial level defines the goals and chooses the optimal alternative (Opricovic \& Tzeng, 2004).

Every problem of multiple-criteria decision-making is always associated with multiple criteria. Cupic et al. (2003) state that criteria represent different dimensions from which alternatives can be observed. In situations when there is a large number of criteria, the criteria can be arranged in a hierarchical sense, which means that one criterion is more important than another, i.e., the main criterion. Also, each main criterion can be associated with several sub-criteria; each sub-criterion can be associated with slightly lower sub-criteria. Diakoulaki et al. (1995) emphasize the association of the weights of criteria in MCDM problems and state that it is the critical stage of the whole decision-making process. Also, Zavadskas and Podvezko (2016) point out the fact that the weights of criteria are of great importance in MCDM. Therefore, the significance of evaluation criteria, i.e., the weights of criteria, is important because it has an impact on the ranking of the results obtained by applying MCMD methods. Srdjevic et al. (2004) also confirm the importance of criteria for solving multi-criteria problems and emphasize the fact that, in the process of the evaluation of alternatives, criteria are crucial for the final decision.

The effectiveness of the personnel selection process largely depends on the defined set of criteria by which the evaluation and the final selection of candidates are conducted. The significance of criteria during the process of personnel selection is specially highlighted in a research study carried out by Kelemenis and Askounis (2010), where they state that criteria should be defined in order to cover the decision-maker's requirements and that they should be related to the specific job description and requirements. A set of the 
necessary evaluation criteria and the required skills that candidates should possess are significant from the company's standpoint because, during the process of recruitment and selection, recruiters always strive to fill the vacant position with the personnel who best meet the evaluation criteria (Karabašević et al., 2015a).

Over time, many approaches that can be used for the defining of criteria weights have been proposed, such as: the AHP method, proposed by Saaty (1977; 1980); the Delphi technique, proposed by Hwang and Lin (1987); the MACBETH method, proposed by Bana e Costa (1992) and Bana e Costa and Vansnick (1993); the SWARA method, proposed by Keršulienë et al. (2010); the FARE method, proposed by Ginevicius (2011); the KEMIRA method, proposed by Krylovas et al. (2014) and so on. Also, some of the existing methods are used in the fuzzy environment in order to determine the relative weights of evaluation criteria, such as Fuzzy AHP (Torfi et al., 2010).

The work is aimed at creating a set of the evaluation criteria for the position of the Sales Manager, as well as at defining the weights of such criteria. Therefore, the paper is organized as follows: in Section 1, the introductory considerations are given; in Section 2, the SWARA method is presented. Section 3 is dedicated to the selection of the evaluation criteria, whereas, finally, the conclusions are presented in Section 4.

\section{Step-wise Weight Assessment Ratio Analysis}

The new Step-wise Weight Assessment Ratio Analysis (SWARA) method was proposed by Kersulienë et al. (2010). According to Kersulienë et al. (2010), one of the main features the SWARA method brings is a possibility of engaging experts in appraising the significance ratio of the criteria in the process of the determination of their weights. In their research, Stanujkic et al. (2015) also especially emphasize the advantages of the SWARA method in comparison with the well-known AHP method, this being so primarily due to a lower number of pairwise comparisons, for which reason it is much easier to apply. Hashemkhani Zolfani et al. (2015) further state that the SWARA method can successfully be used instead of the AHP, the ANP or the FARE methods.

The SWARA method has so far been applied in solving various problems, primarily in determining the weights of criteria, such as: the rational dispute resolution (Kersulienë et al. 2010), the architect selection (Kersulienë \& Turskis, 2011), the design of products (Hashemkhani Zolfani et al., 2013), the machine tool selection (Aghdaie et al., 2013), a supplier selection (Alimardani et al., 2013), wall insulation (Ruzgys et al., 2014), the selection of a packaging design (Stanujkic et al. 2015) and the personnel selection (Kersulienë \& Turskis, 2014; Hashemkhani Zolfani \& Banihashemi, 2014; Karabašević et al., 2015a; 2015b; 2016), the evaluation of strategies (Hashemkhani Zolfani et al., 2015), the ERP system selection (Shukla et al., 2016) and so on.

The procedure for expressing the relative importance between criteria and for the determination of the weights of criteria can be shown in Figure 1.

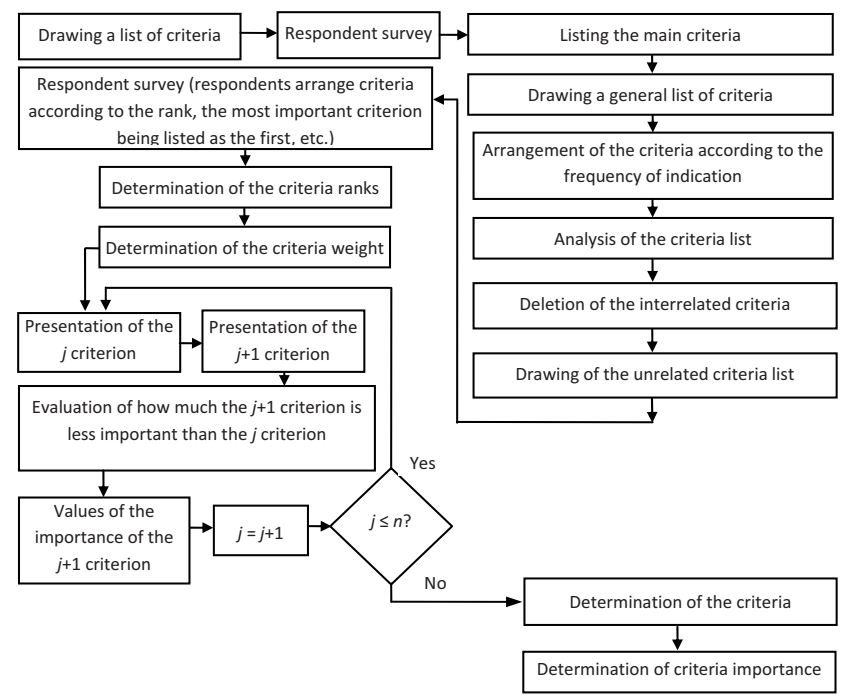

Figure 1: The determination of the weights of criteria based on the application of the SWARA method (Kersulienë et al., 2010) 
The process of the determination of the relative weights of criteria by using the SWARA method based on Kersulienë et al. (2010) is further simplified by Stanujkic et al. (2015) and can be shown through the following steps:

Step 1. The criteria are sorted in the descending order, based on their expected significances.

Step 2. Starting from the second criterion, the respondent expresses the relative importance of the criterion $j$ in relation to the previous $(j-1)$ criterion, and does so for each particular criterion. According to Kersulienë et al. (2010), this ratio is called the Comparative Importance of the Average Value, $s_{j}$.

Step 3. Determine the coefficient $k_{j}$ as follows:

$$
k_{j}=\left\{\begin{array}{cc}
1 & j=1 \\
s_{j}+1 & j>1
\end{array}\right.
$$

Step 4. Determine the recalculated weight $q_{j}$ as follows (Karabašević et al., 2015a):

$$
q_{j}=\left\{\begin{array}{cc}
1 & j=1 \\
\frac{q_{j-1}}{k_{j}} & j>1
\end{array} .\right.
$$

Step 5. The relative weights of the evaluation criteria are determined as follows:

$$
w_{j}=\frac{q_{j}}{\sum_{k=1}^{n} q_{k}},
$$

Where $w_{j}$ denotes the relative weight of the $j$-th criterion, and $n$ denotes the number of the criteria.

\section{An Approach to the Selection of the Sales Manager's Evaluation Criteria, based on the SWARA Method and the Delphi Technique}

The selection of the key criteria, together with associated weights for the position of the sales manager, was conducted through the two cycles of the survey on the total of 79 research participants, out of whom 21 were surveyed in the first round and 58 in the second. The participants in the study were HR managers, HR experts, HR partners, HR experts in recruitment and selection and the sales directors who participated in the selection of sales managers.

For the purpose of determining the weights, the adapted SWARA method (Kersulienë et al., 2010) combined with the Delphi technique (Bowels, 1999) was used. In the proposed integrated approach, some benefits that the Delphi technology permits are used to replace some initial steps of the original SWARA method, or more precisely said, to replace the steps related to the determination of the list of the evaluation criteria. Such an approach should provide an opportunity for the systematic refinement of experts' opinions in order to reach a consensual position. The proposed approach can be shown through the two rounds of the conducted survey, namely as follows:

Round 1 of the survey. The first round, performed in two steps, was conducted in order to identify the most important criteria.

Step 1. The creating of the initial set of the alternatives. The first step involves the creation of the initial set of the general evaluation criteria for the position of the sales manager. The initial set of 10 proposed criteria was obtained on the basis of the studied literature and the interviews with experts in this domain and the representative references are displayed in Table 1. 
Table 1: The initial set of the proposed evaluation criteria

\begin{tabular}{|l|l|}
\hline The proposed evaluation criteria & Representative references \\
\hline $\begin{array}{l}\text { Interview preparedness (CV and personal } \\
\text { presentation) }\end{array}$ & Ruetzler et al. (2010); Popovic et al. (2012). \\
\hline Relevant work experience & $\begin{array}{l}\text { Ruetzler et al. (2010); Popovic et al. (2012); } \\
\text { Boran et al. (2011); Hill and Birdseye (1989); } \\
\text { Bogdanovic and Miletic (2014). }\end{array}$ \\
\hline Education & Popovic et al. (2012); Hill and Birdseye (1989). \\
\hline Interpersonal skills & Ruetzler et al. (2010). \\
\hline Communication and presentation skills & $\begin{array}{l}\text { Biesma et al. (2007); Popovic et al. (2012); } \\
\text { Boran et al. (2011); Bogdanovic and Miletic } \\
\text { (2014). }\end{array}$ \\
\hline $\begin{array}{l}\text { Commitment and aptitude for working with } \\
\text { others (team work) }\end{array}$ & $\begin{array}{l}\text { Ruetzler et al. (2010); Biesma et al. (2007); } \\
\text { Popovic et al. (2012). }\end{array}$ \\
\hline Organizational, leadership and analytical skills & Popovic et al. (2012). \\
\hline Problem solving and strategic thinking & $\begin{array}{l}\text { Biesma et al. (2007); Bogdanovic and Miletic } \\
\text { (2014). }\end{array}$ \\
\hline Computer skills & $\begin{array}{l}\text { Popovic et al. (2012); Bogdanovic and Miletic } \\
\text { (2014). }\end{array}$ \\
\hline Knowledge of foreign languages & $\begin{array}{l}\text { Popovic et al. (2012); Bogdanovic and Miletic } \\
\text { (2014). }\end{array}$ \\
\hline
\end{tabular}

Source: Authors' calculations

The respondents were given an opportunity to make a free choice of the criteria from the proposed initial set or, if they believed they could propose their own set of the evaluation criteria, they were free to do so. It was necessary that the criteria should be entered according to their importance, starting from the most significant and ending with the less significant ones.

Step 2. The creating of the final list of the evaluation criteria upon completion of the first round of the survey. The respondents interviewed in the first round of the survey took the advantage of the possibility of entering their evaluation criteria that differed from the initial set of the proposed criteria. Accordingly, additional 29 criteria were added apart from those criteria, for which reason the set of the criteria at the end of the first round of the survey consisted of a total of 39 criteria shown in Table 2.

Table 2: The list of the evaluation criteria obtained after the completion of the first round of the survey

\begin{tabular}{|l|l|}
\hline \multicolumn{2}{|c|}{ Evaluation criteria } \\
\hline $\begin{array}{l}\text { Interview preparedness (CV and personal } \\
\text { presentation) }\end{array}$ & The appropriate qualifications \\
\hline Relevant work experience & Advanced sales skills and knowledge \\
\hline Education & Self-motivation \\
\hline Interpersonal skills & Leadership skills and their potential \\
\hline Communication and presentation skills & $\begin{array}{l}\text { The ability to analyze problems, reasoning } \\
\text { and decision-making }\end{array}$ \\
\hline $\begin{array}{l}\text { Commitment and aptitude for working with } \\
\text { others (team work) }\end{array}$ & Relevant work experience and references \\
\hline $\begin{array}{l}\text { Organizational, leadership and analytical } \\
\text { skills }\end{array}$ & Leadership and mentoring \\
\hline Problem solving and strategic thinking & Negotiation skills and communication \\
\hline Computer skills & Knowledge of psychology of sales skills \\
\hline Knowledge of foreign languages & Special education (training) \\
\hline Proactivity & Presentation skills \\
\hline Creativity & Problem-solving skills \\
\hline Motivation and dedication to work & $\begin{array}{l}\text { Understanding the needs of potential } \\
\text { customers }\end{array}$ \\
\hline $\begin{array}{l}\text { Organizational, analytical and problem- } \\
\text { solving skills }\end{array}$ & $\begin{array}{l}\text { Communication and presentation skills, } \\
\text { cultural expression, the ability to establish } \\
\text { contact }\end{array}$ \\
\hline Presentation skills and leadership abilities & $\begin{array}{l}\text { Individual competencies (self-initiative, } \\
\text { ability to adapt, ability to harmonize } \\
\text { personal goals in the organization) }\end{array}$ \\
\hline References & $\begin{array}{l}\text { Organizational and leadership skills } \\
\text { initiative to improve and discover new } \\
\text { opportunities, searching for information) }\end{array}$ \\
\hline Appearance & Analytical thinking ability, expert opinion \\
\hline Willingness to learn & Ability to lead teamwork \\
\hline $\begin{array}{l}\text { Impression at the interview (personal } \\
\text { presentation) } \\
\text { employers (work experience) }\end{array}$ & \multicolumn{1}{c|}{ Source: Authors' calculations } \\
\cline { 1 - 2 } & \\
\hline
\end{tabular}


Round 2 of the survey: The second round, which is presented through the three steps further in the text, was conducted with the aim of creating the final set of the evaluation criteria together with the corresponding weights.

Step 1. The criteria reduction in the evaluation criteria list derived from the first round of the survey. The reduction in the number of the selection criteria was made and the 20 evaluation criteria that would be used in the second round of the survey were selected in the following two stages:

- according to the number of the occurrences and

- according to the importance assigned to them in the questionnaire.

The final list of the 20 evaluation criteria obtained after making the reduction is accounted for in Table 3.

Table 3: The final list of 20 evaluation criteria after completing the reduction

\begin{tabular}{|l|l|}
\hline \multicolumn{2}{|c|}{ Evaluation criteria } \\
\hline $\begin{array}{l}\text { Interview preparedness } \\
\text { (CV and personal presentation) }\end{array}$ & Motivation and dedication to work \\
\hline Relevant work experience & Leadership and mentoring \\
\hline Education & Advanced sales skills and knowledge \\
\hline Interpersonal skills & Negotiation skills and communication \\
\hline Communication and presentation skills & Knowledge of psychology of sales skills \\
\hline $\begin{array}{l}\text { Commitment and aptitude for working } \\
\text { with others (team work) }\end{array}$ & $\begin{array}{l}\text { Communication and presentation skills, cultural } \\
\text { expression, the ability to establish contact }\end{array}$ \\
\hline Organizational, leadership and analytical skills & Analytical thinking ability, expert opinion \\
\hline Problem solving and strategic thinking & References \\
\hline Computer skills & $\begin{array}{l}\text { The ability to analyze problems, reasoning and } \\
\text { decision-making }\end{array}$ \\
\hline Knowledge of foreign languages & Special education (training) \\
\hline
\end{tabular}

Source: Authors' calculations

Step 2. The evaluation of the criteria and the creation of the final list of the evaluation criteria together with the corresponding weights during the second round of the survey. During the second round of the survey, the respondents were given the opportunity to choose as many as 7 criteria stated in the list of the criteria shown in Table 3. Then, it was necessary to carry out the comparison of the criteria on the basis of the expected significance, i.e., from the highest to the lowest ones.

Step 3. The modification of the SWARA method for determining the group weights. The normal SWARA approach implies that the selected alternatives have previously been ranked according to the expected importance in a descending order, after which the activity of assigning significance in relation to the $n-1$ alternative is carried out. In order to collect the respondents' more realistic attitudes, the adapted SWARA approach was applied for the purpose of weights assignment at the group level. Accordingly, the respondents were allowed to make a choice of the criteria at their own discretion, after which it was necessary that the criteria should be assigned relative importance, i.e., their corresponding weights. In order to facilitate the evaluation of the criteria, i.e., the assignment of importance, it was recommended that the respondents should (and could) also express relative importance in percentages. Due to the above said, prior to the application of the computational procedure of the SWARA method, it was necessary that the following formula should be applied in order to determine $s_{i .:}$

$$
s_{i}=1-\frac{p_{i}}{100}
$$

Where $p_{i}$ denotes the significance of the criteria (how much the criterion is less significant in relation to the $j$ criterion), while $i$, is expressed in percentages.

Step 3.1. The choice of the evaluation criteria and the determination of the weights on the basis of the second round of the survey. The respondents expressed their relative importance in such a way as explained in the previous step. When the ranking of the criteria according to the mean value of the weights is concerned, an anomaly was noted, namely, that the criteria chosen by a smaller number of the respondents, and with greater importance/weight assigned to them, were given higher rankings. For the purpose of solving the above problem, the following approach was proposed for the purpose of achieving 
a more equitable ranking of the criteria that assigns equal importance to the medium value of the weights and to the sum of the weights in the following manner:

$$
l_{i}=\lambda o_{i}^{\prime}+(1-\lambda) o_{i}^{\prime \prime}
$$

where represents the coefficient, $[0,1], o_{i}^{\prime}$ denotes the rank achieved on the basis of the mean weights of the criteria, $i$, and $O_{i}^{\prime \prime}$ denote the rank achieved on the basis of the sum of the weight of the criteria $i$.

Thereafter, the discussed criteria were ranked in relation to $I_{i}$, after which the selection of the $n$ of the highestranked criteria was performed.

In order to meet the requirement $\sum_{j=1}^{n} w_{j}=1$, the weights of the selected criteria were determined as follows:

$$
w_{j}=\frac{\bar{w}_{j}}{\bar{w}_{t}}
$$

where $\bar{w}_{j}$ denotes the mean weight of the criteria $j$, achieved on the basis of the respondents' attitudes, $\bar{w}_{t}$ denotes the sum of mean weights of all selected criteria $\sum_{j=1}^{n} \bar{w}_{j}$, and $n$ denotes the number of the selected criteria.

Table 4 is the list showing the total of 20 criteria, together with the corresponding weights. The value of the coefficient is 0.5 .

\begin{tabular}{|c|c|c|c|c|c|c|c|c|}
\hline Criteria & $\begin{array}{l}\text { Mean } \\
\text { weights } \\
\text { of } \\
\text { criteria } i\end{array}$ & $\begin{array}{c}\text { Rank to } \\
\text { the } \\
\text { mean } \\
\text { weights } \\
O_{i}^{\prime}\end{array}$ & $\begin{array}{l}\text { Sum of } \\
\text { the } \\
\text { weights } \\
\text { of } \\
\text { criteria } i\end{array}$ & $\begin{array}{c}\text { Rank to } \\
\text { the sum } \\
\text { of } \\
\text { weights } \\
- \\
O_{i}^{\prime \prime}\end{array}$ & $\begin{array}{c}\text { Coefficient } \\
\lambda \text { for } O_{i}^{\prime} \text { is } \\
0.5\end{array}$ & $\begin{array}{l}\text { Coefficient } \\
\lambda \text { for } O_{i}^{\prime \prime} \text { is } \\
0.5\end{array}$ & $\begin{array}{c}\text { Aggregated } \\
\operatorname{rank} l_{i}\end{array}$ & $\begin{array}{l}\text { Final } \\
\text { rank }\end{array}$ \\
\hline & $\max$ & $\min$ & $\max$ & $\min$ & 0.5 & 0.5 & 1 & \\
\hline $\begin{array}{l}\text { Communication } \\
\text { and presentation } \\
\text { skills }\end{array}$ & 0.231 & 1 & 6.464 & 3 & 0.5 & 1.5 & 1 & 1 \\
\hline $\begin{array}{l}\text { Interpersonal } \\
\text { skills }\end{array}$ & 0.122 & 11 & 3.905 & 10 & 5.5 & 5 & 5.25 & 11 \\
\hline $\begin{array}{l}\text { Relevant work } \\
\text { experience }\end{array}$ & 0.191 & 3 & 8.776 & 1 & 1.5 & 0.5 & 1 & 1 \\
\hline $\begin{array}{l}\text { Commitment and } \\
\text { aptitude for } \\
\text { working with } \\
\text { others (team } \\
\text { work) }\end{array}$ & 0.127 & 10 & 4.564 & 7 & 5 & 3.5 & 4.25 & 8 \\
\hline Education & 0.149 & 6 & 5.073 & 5 & 3 & 2.5 & 2.75 & 4 \\
\hline $\begin{array}{l}\text { Organizational, } \\
\text { leadership and } \\
\text { analytical skills }\end{array}$ & 0.129 & 9 & 5.165 & 4 & 4.5 & 2 & 3.25 & 6 \\
\hline $\begin{array}{l}\text { Problem solving } \\
\text { and strategic } \\
\text { thinking }\end{array}$ & 0.111 & 12 & 4.001 & 8 & 6 & 4 & 5 & 10 \\
\hline $\begin{array}{l}\text { Interview } \\
\text { preparedness } \\
\text { (CV and } \\
\text { personal } \\
\text { presentation) }\end{array}$ & 0.195 & 2 & 7.021 & 2 & 1 & 1 & 1 & 1 \\
\hline Computer skills & 0.129 & 8 & 0.259 & 18 & 4 & 9 & 6.5 & 13 \\
\hline $\begin{array}{l}\text { Knowledge of } \\
\text { foreign } \\
\text { languages }\end{array}$ & 0.059 & 16 & 0.473 & 14 & 8 & 7 & 7.5 & 15 \\
\hline
\end{tabular}

Table 4: The final ranking of the 20 evaluation criteria after the completion of the second round of the survey 


\begin{tabular}{|c|c|c|c|c|c|c|c|c|}
\hline Criteria & $\begin{array}{l}\text { Mean } \\
\text { weights } \\
\text { of } \\
\text { criteria } i\end{array}$ & $\begin{array}{c}\text { Rank to } \\
\text { the } \\
\text { mean } \\
\text { weights } \\
O_{i}^{\prime}\end{array}$ & $\begin{array}{l}\text { Sum of } \\
\text { the } \\
\text { weights } \\
\text { of } \\
\text { criteria } i\end{array}$ & $\begin{array}{c}\text { Rank to } \\
\text { the sum } \\
\text { of } \\
\text { weights } \\
O_{i}^{\prime \prime}\end{array}$ & $\begin{array}{c}\text { Coefficient } \\
\lambda \text { for } O_{i}^{\prime} \text { is } \\
0.5\end{array}$ & $\begin{array}{c}\text { Coefficient } \\
\lambda \text { for } O_{i}^{\prime \prime} \text { is } \\
0.5\end{array}$ & $\begin{array}{l}\text { Aggregated } \\
\text { rank } l_{i}\end{array}$ & $\begin{array}{l}\text { Fina } \\
\text { rank }\end{array}$ \\
\hline & $\max$ & $\min$ & $\max$ & $\min$ & 0.5 & 0.5 & 1 & \\
\hline $\begin{array}{l}\text { Motivation and } \\
\text { dedication to } \\
\text { work }\end{array}$ & 0.156 & 5 & 4.668 & 6 & 2.5 & 3 & 2.75 & 4 \\
\hline $\begin{array}{l}\text { Leadership and } \\
\text { mentoring }\end{array}$ & 0.075 & 14 & 0.895 & 12 & 7 & 6 & 6.5 & 13 \\
\hline $\begin{array}{l}\text { Advanced sales } \\
\text { skills and } \\
\text { knowledge }\end{array}$ & 0.141 & 7 & 3.940 & 9 & 3.5 & 4.5 & 4 & 7 \\
\hline $\begin{array}{l}\text { Negotiation skills } \\
\text { and } \\
\text { communication }\end{array}$ & 0.108 & 13 & 1.075 & 11 & 6.5 & 5.5 & 6 & 12 \\
\hline $\begin{array}{l}\text { Knowledge of } \\
\text { psychology of } \\
\text { sales skills }\end{array}$ & 0.072 & 15 & 0.289 & 17 & 7.5 & 8.5 & 8 & 16 \\
\hline $\begin{array}{l}\text { Communication } \\
\text { and presentation } \\
\text { skills, cultural } \\
\text { expression, the } \\
\text { ability to } \\
\text { establish contact }\end{array}$ & 0.170 & 4 & 0.678 & 13 & 2 & 6.5 & 4.25 & 8 \\
\hline $\begin{array}{l}\text { Analytical } \\
\text { thinking ability, } \\
\text { expert opinion }\end{array}$ & 0.051 & 17 & 0.308 & 15 & 8.5 & 7.5 & 8 & 16 \\
\hline References & 0.031 & 19 & 0.306 & 16 & 9.5 & 8 & 8.75 & 18 \\
\hline $\begin{array}{l}\text { The ability to } \\
\text { analyze } \\
\text { problems, } \\
\text { reasoning and } \\
\text { decision-making }\end{array}$ & 0.047 & 18 & 0.094 & 19 & 9 & 9.5 & 9.25 & 19 \\
\hline $\begin{array}{l}\text { Special } \\
\text { education } \\
\text { (trainings) }\end{array}$ & 0.020 & 20 & 0.039 & 20 & 10 & 10 & 10 & 20 \\
\hline
\end{tabular}

Source: Authors' calculations

Table 5 shows the final selection and the final ranking of the best-placed criteria. The table also shows the original weights of the criteria and the adjusted weights of the criteria in order to satisfy the requirement that the sum of the weights results in the value 1.

Table 5: The 7 top-ranked criteria together with the corresponding weights and the corrected weights

\begin{tabular}{|c|l|c|c|}
\hline Rank & Criteria & Weights & $\begin{array}{c}\text { Corrected } \\
\text { weights }\end{array}$ \\
\hline 1 & Communication and presentation skills & 0.231 & 0.194 \\
\hline 1 & Relevant work experience & 0.191 & 0.160 \\
\hline 1 & $\begin{array}{l}\text { Interview preparedness } \\
\text { (CV and personal presentation) }\end{array}$ & 0.195 & 0.164 \\
\hline 4 & Motivation and dedication to work & 0.156 & 0.131 \\
\hline 4 & Education & 0.149 & 0.125 \\
\hline 6 & Organizational, leadership and analytical skills & 0.129 & 0.108 \\
\hline 7 & Advanced sales skills and knowledge & 0.141 & 0.118 \\
\hline & & 1.191 & 1.000 \\
\hline
\end{tabular}

Source: Authors' calculations 
At the beginning of the research study, the initial set of 10 criteria belonging to the criteria displayed in Table 1 was created. If we compare the final list of the criteria after conducting the survey from Table 5 with the criteria initially proposed in Table 1 , we can notice that the five of these criteria (Communication and presentation skills; Relevant work experience; Interview preparedness (CV and personal presentation); Education and Organizational, leadership and analytical skills) come from the initial list of the proposed criteria, which suggests that, at the start of the research study, the criteria were well-selected, based on the thoroughly investigated literature and interviews with the experts in this domain.

On the basis of the research and the opinions of the experts in the field of human resources, we can notice that, in the process of the recruitment and selection of sales managers, decision-makers pay special attention to the above criteria. Thus, it is necessary for a sales manager to be communicative and to have good presentation skills, a relevant work experience qualifying him/her for election, to be well-prepared for the interview, motivated for and dedicated to his/her work, i.e., to strive to achieve the company goals, to be so educated that he or she has organizational, analytical and sales skills, and ultimately - to be a leader.

Conslusion

As an expert-oriented method, the SWARA method has proved to be extremely suitable for testing respondents', i.e., experts' attitudes. The adapted SWARA method is successfully applied in the work in order to determine the weights of the criteria. The set of the criteria for the selection of sales managers, together with their corresponding weights, is successfully defined by applying this approach. The adapted SWARA method has proved to be very suitable for problem solving from the very beginning of the research study. Initially, the planned approach was solely based on the application of the SWARA method; in order to make the study closer to the respondents, however, the above method was also modified to a certain extent. The proposed approach has successfully responded to the requirements in terms of defining the criteria and determining the weights of the criteria. The applicability and ease of use of the proposed approach has proved to be useful and can be applied in order to determine the weights, differently from the traditional approaches based, for example, on the AHP method, and the same can be used for the examination of the attitudes of experts in other areas as well, depending on the problem that is being considered.

\section{REFERENCES}

[1] Aghdaie, M. H., Hashemkhani Zolfani, S., \&Zavadskas, E. K. (2013). Decision making in machine tool selection: An integrated approach with SWARA and COPRAS-G methods. Inzinerine Ekonomika -Engineering Economics, 24(1), 5-17. DOI: 10.5755/j01.ee.24.1.2822

[2] Alimardani, M., Hashemkhani Zolfani, S., Aghdaie, M. H., \&Tamošaitienè, J. (2013). A novel hybrid SWARA and VIKOR methodology for supplier selection in an agile environment. Technological and Economic Development of Economy, 19(3), 533-548.

[3] Bana e Costa, C. A. (1992). Structuration, construction et exploitation d'un modèle multicritère d'aide à la décision. PhD thesis, Technical University of Lisbon, Lisbon.

[4] Bana e Costa, C. A., \&Pirlot, M. (1997). Thoughts on the future of the multicriteria field: Basic convictions and outline for a general methodology. In Multicriteria Analysis (pp. 562-568). Berlin, Heidelberg: Springer.

[5] Bana e Costa, C.A, \&Vansnick, J.C. (1993). Sur la quantification des jugements de valeur: L'approche MACBETH. Cahiers du LAMSADE. Paris: Universit'e Paris Dauphine.

[6] Biesma, R. G., Pavlova, M., Merode Van G. G., \& Groot, W. (2007). Using conjoint analysis to estimate employers preferences for key competencies of master level Dutch graduates entering the public health field. Economics of Education Review, 26, 375-386. DOI: 10.1016/j.econedurev.2006.01.004

[7] Bogdanovic, D., \& Miletic, S. (2014). Personnel Evaluation and Selection by Multicriteria Decision Making Method. Economic computation and economic cybernetics studies and research, 48(3), 179-196.

[8] Boran, F. E., Genc, S. \&Akay, D. (2011). Personnel Selection Based on Intuitionistic Fuzzy Sets. Human Factors and Ergonomics in Manufacturing \& Service Industries, 21 (5), 493-503. DOI: $10.1002 / \mathrm{hfm} .20252$

[9] Bowels, N. (1999). The Delphi technique. RCNi, 13, 32-6.

[10] Cupic, M. E., Tumala, V. R., \& Suknovic, M. M. (2003). Odlučivanje: formalni pristup. Beograd: Fakultet organizacionih nauka. 
[11] Diakoulaki, D., Mavrotas, G., \&Papayannakis, L. (1995). Determining objective weights in multiple criteria problems: the CRITIC method. Computers \& Operations Research, 22(7), 763-770. DOI: 10.1016/0305-0548(94)00059-H

[12] Duckstein, L., \&Opricovic, S. (1980). Multiobjective optimization in river basin development. Water Resources Research, 16(1), 14-20. DOI: 10.1029/WR016i001p00014

[13] Ginevicius, R. (2011). A new determining method for the criteria weights in multicriteria evaluation. International Journal of Information Technology \& Decision Making, 10(06), 1067-1095. DOI: 10.1142/S0219622011004713

[14] Hajiagha, S. H. R., Hashemi, S. S., Mohammadi, Y., \&Zavadskas, E. K. (2016). Fuzzy belief structure based VIKOR method: an application for ranking delay causes of Tehran metro system by FMEA criteria. Transport, 31(1), 108-118. DOI: 10.3846/16484142.2016.1133454

[15] Hashemkhani Zolfani, S, Maknoon R, \&Zavadskas E. K. (2015). Multiple Nash equilibriums and evaluation of strategies; new application of MCDM methods. Journal of Business Economics and Management, 16(2), 290-306. DOI: 10.3846/16111699.2014.967715

[16] Hashemkhani Zolfani, S., \&Banihashemi, S. S. A. (2014). Personnel selection based on a novel model of game theory and MCDM approaches. in Proc. of 8th International Scientific Conference "Business and Management 2014", 15-16 May 2014, Vilnius, Lithuania, 191-198. DOI: 10.3846/bm.2014.024

[17] Hashemkhani Zolfani, S., Zavadskas, E. K., \&Turskis, Z. (2013). Design of products with both International and Local perspectives based on Yin-Yang balance theory and SWARA method. Ekonomska istraživanja-Economic Research, 26(2), 153-166. DOI: 10.1080/1331677X.2013.11517613

[18] Hill, J., \& Birdseye, M. (1989). Salesperson Selection in Multinational Corporations: An empirical study. Journal of Personal Selling \& Sales Management, 9, 39-47.

[19] Hwang, C. L., \& Lin, M. J. (1987). Group Decision Making Under Multiple Criteria: Methods and Applications. Berlin: Springer-Verlag.

[20] Karabasevic, D., Stanujkic, D., \& Urosevic, S. (2015a). The MCDM model for personnel selection based on SWARA and ARAS methods. Management, 77, 43-52. DOI: 10.7595/management.fon.2015.0029

[21] Karabasevic, D., Stanujkic, D., Urosevic, S., \&Maksimovic, M. (2015b). Selection of candidates in the mining industry based on the application of the SWARA and the MULTIMOORA methods. Acta Montanistica Slovaca, 20(2), 116-124.

[22] Karabasevic, D., Stanujkic, D., Urosevic, S., \& Maksimovic, M. (2016). An approach to personnel selection based on Swara and Waspas methods. Bizinfo (Blace), 7(1), 1-11. DOI: 10.5937/bizinfo1601001K

[23] Kelemenis, A., \&Askounis, D. (2010). A new TOPSIS-based multi-criteria approach to personnel selection. Expert Systems with Applications, 37(7), 4999-5008. DOI: 10.1016/j.eswa.2009.12.013

[24] Kersuliene, V., \&Turskis, Z. (2011). Integrated fuzzy multiple criteria decision making model for architect selection. Technological and Economic Development of Economy, 17(4), 645-666. DOI:10.3846/20294913.2011.635718

[25] Kersuliene, V., \&Turskis, Z. (2014). An integrated multi-criteria group decision making process: selection of the chief accountant. Procedia - Social and Behavioral Sciences, 110, 897-904. DOI: 10.1016/j.sbspro.2013.12.935

[26] Kersuliene, V., Zavadskas, E. K., \&Turskis, Z. (2010). Selection of rational dispute resolution method by applying new step-wise weight assessment ratio analysis (SWARA). Journal of Business Economics and Management, 11(2), 243-258.

[27] Krylovas, A., Zavadskas, E. K., Kosareva, N., \&Dadelo, S. (2014). New KEMIRA method for determining criteria priority and weights in solving MCDM problem. International Journal of Information Technology \& Decision Making, 13(06), 1119-1133. DOI: 10.1142/S0219622014500825

[28] Opricovic, S., \&Tzeng, G. H. (2004). Compromise solution by MCDM methods: A comparative analysis of VIKOR and TOPSIS. European journal of operational research, 156(2), 445-455. DOI: $10.1016 / \mathrm{S} 0377-2217(03) 00020-1$

[29] Popovic, M., Kuzmanovic, M., \& Martic, M. (2012). Using Conjoint Analysis to Elicit Employers' Preferences Toward Key Competencies for a Business Manager Position. Management, 63, 17-26.

[30] Ruetzler, T., Taylor, J., Reynolds, D., \& Baker, W. (2010). Assessing Professional Attributes using Conjoint Analysis. International CHRIE Conference, 28-31 July, 2010, San Juan, Puerto Rico.

[31] Ruzgys, A., Volvačiovas, R., Ignatavičius, Č., \&Turskis, Z. (2014). Integrated evaluation of external wall insulation in residential buildings using SWARA-TODIM MCDM method. Journal of Civil Engineering and Management, 20(1), 103-110. DOI: 10.3846/13923730.2013.843585

[32] Saaty, T. L. (1977). A scaling method for priorities in hierarchical structures. Journal of mathematical psychology, 15(3), 234-281. DOI: 10.1016/0022-2496(77)90033-5 
[33] Saaty, T. L. (1980). The Analytic Hierarchy Process: Planning, Priority Setting, Resource Allocation. New York: McGraw-Hill.

[34] Shukla, S., Mishra, P. K., Jain, R., \& Yadav, H. C. (2016). An integrated decision making approach for ERP system selection using SWARA and PROMETHEE method. International Journal of Intelligent Enterprise, 3(2), 120-147. DOI: 10.1504/IJIE.2016.076041

[35] Srdjevic, B., Potkonjak, S., Srdjevic, Z., Skoric, M., \& Zoranovic, T. (2004). Simulacija grupnog odlučivanja u izboru tehnologije navodnjavanja. Poljoprivreda između suša i poplava, Poljoprivredni fakultet, Novi Sad, 126-133.

[36] Stanujkic, D., Karabasevic, D., \&Zavadskas, E. K. (2015). A framework for the Selection of a packaging design based on the SWARA method. Inzinerine Ekonomika -Engineering Economics, 26(2), 181-187. DOI: 10.5755/j01.ee.26.2.8820

[37] Torfi, F., Farahani, R. Z., \&Rezapour, S. (2010). Fuzzy AHP to determine the relative weights of evaluation criteria and Fuzzy TOPSIS to rank the alternatives. Applied Soft Computing, 10(2), 520-528. DOI: 10.1016/j.asoc.2009.08.021

[38] Zavadskas, E. K., \&Podvezko, V. (2016). Integrated Determination of Objective Criteria Weights in MCDM. International Journal of Information Technology \& Decision Making, 15(02), 267-283. DOI: $10.1142 /$ S0219622016500036

Received: 2016-07-18

Accepted: 2017-10-11

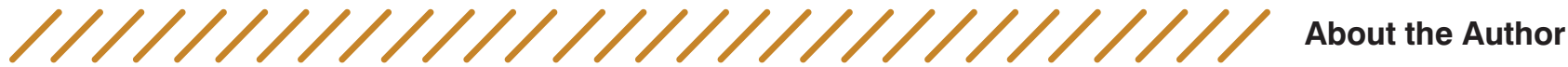

\section{Darjan Karabasevic \\ Faculty of Applied Management, Economics and Finance, University Business Academy in Novi Sad, Jevrejska 24, Belgrade, Serbia darjan.karabasevic@mef.edu.rs}

Dr. Darjan Karabasevic is an assistant professor of Management at the Faculty of Applied Management, Economics and Finance, University Business Academy in Novi Sad. He obtained his degrees at all the levels of studies (B.Sc. appl. in Economics,

B.Sc. in Economics, Academic Specialization in the Management of Business Information Systems and Ph.D. in Management and Business) at the Faculty of

Management in Zajecar, John Naisbitt University, Belgrade. His current research is focused on human resource management, management and decision-making theory.

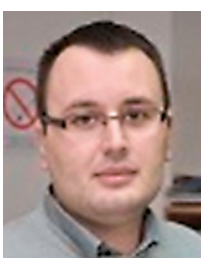

Dragisa Stanujkic Faculty of Management Zaječar, John Naisbitt University Belgrade, Park Šuma "Kraljevica" bb, 19000 Zaječar, Serbia dragisa.stanujkic@fmz.edu.rs

Dragisa Stanujkic, Ph.D., is a full professor of Information Technology and Decision Sciences at the Faculty of Management in Zaječar, John Naisbitt University in Belgrade. He obtained his M.Sc. degree in Information Science and his Ph.D. degree in Organizational Sciences at the Faculty of Organizational Sciences, Belgrade University. His current research is focused on decision-making theory, expert systems and

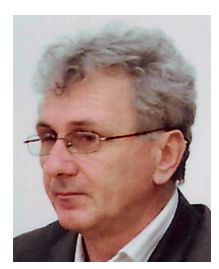
intelligent decision support systems. 


\section{Snezana Urosevic \\ Technical Faculty in Bor, University of Belgrade, Vojske Jugoslavije 12, Bor, Serbia surosevic@tt.bor.ac.rs}

Snezana Urosevic, Ph.D., is an associate professor. She defended her doctoral thesis at the Technical Faculty "Mihajlo Pupin" in Zrenjanin, University of Novi Sad, in 2007, in the field of management. She has published 15 papers in international SCl journals. She is a member of the editorial boards of several national and international journals, a member of the scientific boards of several international conferences, and is currently a

researcher in two national projects. Her areas of interest include Human Resource Management and Environmental Management

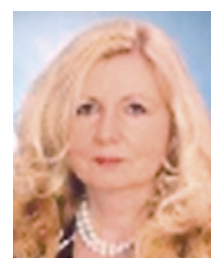

Gabrijela Popovic Faculty of Management Zaječar, John Naisbitt University Belgrade, Park Šuma "Kraljevica" bb, 19000 Zaječar, Serbia gabrijela.popovic@fmz.edu.rs

Gabrijela Popovic, Ph.D., is an assistant professor of Project Management and Investment Project Management at the Faculty of Management in Zaječar, John Naisbitt University Belgrade. She obtained her M.Sc. degree in Economics and her Ph.D. degree in Management and Business at the Faculty of Management in Zaječar, John Naisbitt University, Belgrade. Her current research involves decision-making theory, project management and environmental and natural resource economics.

Mladjan Maksimovic

Faculty of Applied Management, Economics and Finance, University Business Academy in Novi Sad, Jevrejska 24, Belgrade, Serbia mladjan.maksimovic@mef.edu.rs

Mladjan Maksimovic, Ph.D., is an assistant professor of Management at the Faculty of Applied Management, Economics and Finance, University Business Academy in Novi Sad. He obtained his B.Sc., M.Sc. and Ph.D. degrees in Management at the Faculty of Management in Zaječar, John Naisbitt University, Belgrade. His current research is focused on management, sustainable development and tourism.

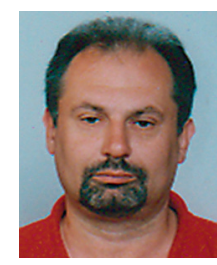

